\title{
Anticataract Activity of Ethanolic Extract of Garcinia Mangostana Linn Pericarp on Glucose-induced Cataractogenesis in Goat Lens
}

\author{
Muhammad Ali Faisal ${ }^{1,2 *}$, Ika Kustiah Octavianty ${ }^{3}$, Hidayat Sujuti ${ }^{4}$, Achmad Rudijanto ${ }^{5}$ \\ ${ }^{1}$ Doctoral Program of Medical Science, Faculty of Medicine, Universitas Brawijaya, Malang, Indonesia; ${ }^{2}$ Department of \\ Ophthalmology, Faculty of Medicine, Lambung Mangkurat University, Banjarmasin, Indonesia; ${ }^{3}$ Department of Pathology \\ Anatomy, Faculty of Medicine, Lambung Mangkurat University, Banjarmasin, Indonesia; ${ }^{4}$ Department of Biochemistry, Faculty \\ of Medicine, Brawijaya University, Malang, Indonesia; ${ }^{5}$ Department of Internal Medicine, Faculty of Medicine, Brawijaya \\ University, Malang, Indonesia
}

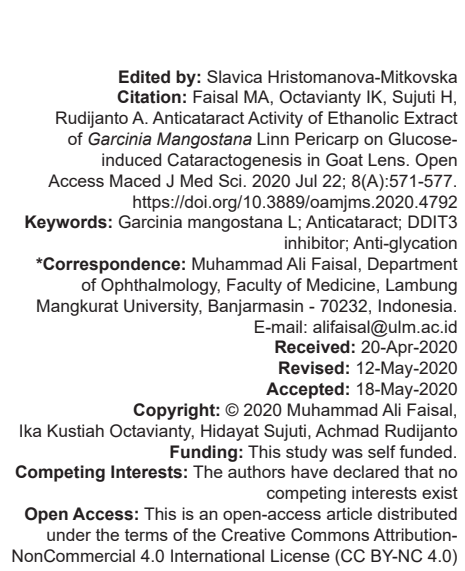

Introduction

The occurrence of diabetes mellitus (DM) is growing day-to-day, with the estimated number of patients reached 578 million at the year of 2030 as predicted by the International Diabetes Federation [1]. Aged people and extended patient lifespan probability correspondingly causes the pervasiveness of DM which will surpass 33\% not later than 2050 [2]. Since diabetic sufferers possess a higher possibility of having cataract, especially become vulnerable to get cortical and posterior subcapsular opacities, they offer for operation at an immediate age [3]. Hyperglycemia is the introducing grounds of the tissue impairment happening in diabetes, either by way of recurrent severe vicissitudes in cellular glucose metabolism, or by way of the continuing increase of glycated biomolecules and advanced glycation end products (AGEs) [4]. The development of cataractogenesis in people with diabetic is faster when contrasted with senile subjects with no less than 20 years ahead onset [5]. Diabetic sufferers have 2-5 times higher probability to develop cataract and bigger tendency to gain it at a younger age [6]. Operation of cataract is a usual and secures way, nonetheless can be related with eyesight-endangering complications for the people with diabetic, such as diabetic retinopathy progression, diabetic macular edema, post-operative macular edema, and posterior capsular opacification [7].

Numerous dissimilar pathogenetic methods which might trigger growth of diabetic cataracts have been offered: Augmented oxidative stress, nonenzymatic glycation of lens proteins, and augmented osmotic stress produced by activation of the polyol pathway [6].

Protein glycation is started by reaction between a free amino group and the sugar carbonyl group to develop a reversible Schiff base (in a period of hours). The later can reposition to be a stable ketoamine or amadori product (over a period of days). Protein glycation is an impulsive reaction reliant in vivo on the level and length of hyperglycemia. The amadori product is able to be changed (in a period 
of weeks) into reactive dicarbonyl products such as glucosones to produce AGEs, such as glucosepane. The Amadori product can also be fragmented by oxidation (glycoxidation) to form AGEs such as carboxymethyllysine (CML) or pentosidine. AGEs pile up mostly in proteins with long half-life, such as extracellular matrix collagens [8]. AGEs have a critical role in loss of lens transparency [5].

Latest proof implies that AGEs hold a tendency to produce reactive oxygen species (ROS). Glucose and other aldehydes, free or protein-bound, can experience auto-oxidation reactions and form radicals and other reactive intermediates (e.g., $\mathrm{H}_{2} \mathrm{O}_{2}$ and other peroxides) that participate in AGE formation. The activity is frequently called glycoxidation [9]. $\alpha$-crystallin glycation might trigger protein unfolding, whereas in hyperglycemic situation the identical process has shown to be intensified many folds [10].

The molecular mechanisms which could be comprised in diabetic cataract include polyol pathway flux, osmotic stress, elevated oxidative stress, and increased formation of AGEs [11]. Potential therapeutics to reduce dicarbonyls and AGE formation have to be improved at scavenging dicarbonyls, alternative pathways for the diminution of $A G E$ formation, for example, transition metal chelation to decrease the autoxidative fragmentation of glucose may be pursued [12].

Garcinia mangostana Linn (GML) (mangosteen, Clusiaceae) has an extensive record of use as a medical plant, mainly in Southeast Asia. Mangosteen has excessive quantities of xanthones, a class of poly phenolic compounds which were shown to have significant biological activities in in vitro systems [13]. Water extracts of mangosteen possesses as the scavenging activity of the free-radical DPPH and neuro protective activity by inhibiting oxidative stress in vitro and inhibition of pentosidine formation in vivo [14].

\section{Material and Methods}

\section{Ethical issue}

The committee of ethics of Medical Faculty of Lambung Mangkurat University has approved this research according to the decree of SKNO: 93/KEPK-FK UNLAM/EC/III/2019 on the principle of $3 \mathrm{R}$ (reduction, replacement, refinement).

\section{Plant sample}

Fresh GML fruits from Central Kalimantan forest were purchased from local market in Kuala Kapuas, Indonesia, in March 2018, and have been identified and extracted at Chemical Analysis
Laboratory, Faculty of Agriculture, Lambung Mangkurat University, Banjarbaru, South Kalimantan.

\section{Extraction of GML pericarp}

Reflux method and ethanol solvent purple color GML fruit is washed and then peeled. GML pericarp is cut and reduced in size until the diameter reaches an average of $2 \mathrm{~cm}$. Pieces of mangosteen pericarp were dried in the room so as not to be exposed to direct sunlight. A total of $250 \mathrm{~g}$ of the dried sample was put into an extraction flask to be extracted with ethanol (96\%) as much as $2000 \mathrm{ml}$. The extraction process was carried out at $75^{\circ} \mathrm{C}$ for $5 \mathrm{~h}$ on a heating mantle through the reflux process. The extraction process was repeated 3 times to really get the maximum extract. The extract solution is filtered using filter paper, and then evaporated using a rotary vacuum evaporator to obtain dry ethanol extract. The dried extract obtained was $19.27 \mathrm{~g}$ or with a yield of $7.71 \%$.

\section{Collection of eye balls}

The goat eye balls used in this study were taken from 7 to 12 months old and healthy female goats (Capra aegagrus hircus) from the slaughter house, $\mathrm{RPH}$ Kambing Kota Malang, straightaway after the butchery. The eye balls, at the temperature of $0-4^{\circ} \mathrm{C}$, were directly transported to the laboratory of Biomedic of Brawijaya University. The sklera was sliced from the behind of the eye to get access to the lens.

\section{Whole lens culture}

The goat eye lenses were separated into five groups. The lenses in the first group (Group I) were incubated in M199 medium (Gibco, Rockville, MD) supplemented with $100 \mathrm{U} / \mathrm{ml}$ penicillin and $0.1 \mathrm{mg} / \mathrm{ml}$ streptomycin in a $37^{\circ} \mathrm{C}$ incubator with $95 \% \mathrm{O}_{2}$ and $5 \% \mathrm{CO}_{2}$ for $120 \mathrm{~h}$. This group served as the normal control. The lenses in the second group were incubated in medium of M199 added by concentration of glucose of $30 \mathrm{mM}$. This group served as toxic control. Groups III, IV, and V lenses incubated in M199 medium with the concentration of glucose of $30 \mathrm{mM}$ were incubated along with GML pericarp extract 100, 500, and 1000 $\mu \mathrm{g} / \mathrm{ml}$ at room temperature for $120 \mathrm{~h}$ and subjected to morphological and biochemical evaluation. Biochemical parameters such as MDA, AGE-CML, GRP78, DDIT3/ $\mathrm{CHOP}$, and active caspase 3 levels of lens homogenate were estimated.

\section{Groups design}

- $\quad$ Group I: Glucose of $5.5 \mathrm{mM}$ (negative control) - $\quad$ Group II: Glucose of 30 mM (positive control/ induced) 
Group III: Glucose of $30 \mathrm{mM}+\mathrm{GML}$ pericarp ethanol extract $(100 \mu \mathrm{g} / \mathrm{ml})$

- Group IV: Glucose of $30 \mathrm{mM}+\mathrm{GML}$ pericarp ethanol extract $(500 \mu \mathrm{g} / \mathrm{ml})$

- Group V: Glucose of $30 \mathrm{mM}+\mathrm{GML}$ pericarp ethanol extract $(1000 \mu \mathrm{g} / \mathrm{ml})$.

\section{Photographic evaluation}

Lenses were placed in a clear culture glass with the posterior surface touching the glass, the crossed striped pattern paper placed under the glass. The pattern of crossed striped number of squares clearly visible through the lens was observed to measure lens opacity. The degree of opacity was graded as follows:

- $\quad$ Grade 0: Absence of opacity

- $\quad$ Grade 1: Slight degree of opacity

- $\quad$ Grade 2: Presence of diffuse opacity

- Grade 3: Presence of extensive thick opacity.

\section{MDA assay using NWLSS ${ }^{\mathrm{TM}}$}

The tissues were minced into little slices and homogenized in a specific extent of PBS (usually $10 \mathrm{mg}$ tissue to $100 \mu \mathrm{l}$ PBS.). Afterward, the homogenates were centrifuged homogenates for about $15 \mathrm{~min}$ at $1500 \times \mathrm{g}$ (or $5000 \mathrm{rpm}$ ). Later, the supernatants were cautiously gathered, directly assayed, or stored the samples at the temperature of $-20^{\circ} \mathrm{C}$ or $-80^{\circ} \mathrm{C}$. Repetitions of cycles of freeze/thaw were avoided. Each of the lens samples was analyzed by MDA using NWLSS ${ }^{\mathrm{TM}}$ Malondialdehyde Assay, per the manufacturer's protocol.

\section{AGE-CML, GRP78/BiP, DDIT3/CHOP, and} active caspase 3 assay using enzyme-linked immunosorbent assay (ELISA)

The tissues were minced to little cuts pieces and homogenized in a specific quantity of PBS (usually $10 \mathrm{mg}$ tissue to $100 \mu \mathrm{l} \mathrm{PBS}$.). Next, the homogenates were centrifuged homogenates for roughly $15 \mathrm{~min}$ at $1500 \times g$ (or $5000 \mathrm{rpm}$ ). Afterward, the supernatants were gathered with care, instantly assayed or stored the samples at the temperature of $-20^{\circ} \mathrm{C}$ or $-80^{\circ} \mathrm{C}$. Repeated freeze/thaw cycles were avoided. Lens AGE-CML levels were measured using a commercially available ELISA Kit (Goat carboxymethyl lysine-AGE ELISA Kit, MyBioSource.com, Cat No. MBS264584), per the manufacturer's protocol. Lens GRP78 levels were measured using a commercially available ELISA Kit (Goat Glucose Regulated Protein 78 (GRP78) ELISA Kit, MyBioSource.com, Catalog Number: MBS021399), per the manufacturer's protocol. Lens DDIT3 levels were measured using a commercially available ELISAKit (Goat DNA Damage Inducible Transcript 3 ELISA Kit (DDIT3), MyBioSource.com, Catalog Number: MBS749160), per the manufacturer's protocol. Lens active caspase
3 levels were measured using a commercially available ELISA Kit (Goat Active caspase-3 ELISA Kit, MyBioSource.com, Catalog Number: MBS7216576), per the manufacturer's protocol.

\section{Statistical analysis}

The data of MDA were analyzed using ANOVA followed by Tukey HSD $(\alpha=0.05)$. The data of AGECML, GRP78, DDIT3, and active caspase 3 were analyzed using Kruskal-Wallis, followed by MannWhitney $(\alpha=0.05)$.

\section{Results}

The effect of the ethanol extract of GML pericarp against glucose induced cataract

The administration of high glucose concentration ( $30 \mathrm{mM}$ ) to the Group II (positive control) caused an increase of MDA, AGE-CML, DDIT3/CHOP, and active caspase 3 level, except GRP78 on the lens capsule. GRP78/BiP level in negative control (Group I) was measured higher in the lens capsule compared to the lens cortex and nucleus. These data indicate that unfolded protein occurs mostly on lens capsules.

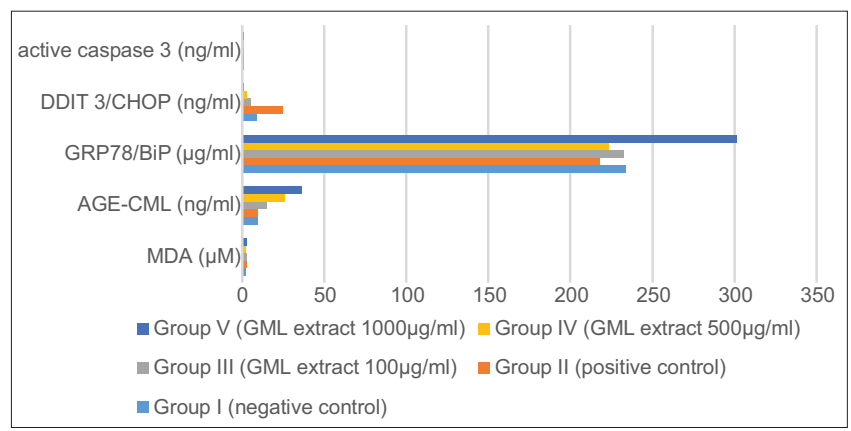

Figure 1: MDA, AGE-CML, GRP78/Bip, DDIT3/CHOP, and active caspase 3 level in lens capsule

As shown in Figure 1 and Table 1 , the administration of GML pericarp extract to the Groups III, IV, and $\mathrm{V}$ has decreased the MDA, DDIT3/CHOP, and active caspase 3 levels. The GRP78 and AGE-CML level did not decreased by the administration of GML

Table 1: MDA, AGE-CML, GRP78/Bip, DDIT3/CHOP, and active caspase 3 level in lens capsule

\begin{tabular}{|c|c|c|c|c|c|}
\hline Groups & MDA & $\begin{array}{l}\text { AGE- } \\
\text { CML }\end{array}$ & $\begin{array}{l}\text { GRP78/ } \\
\text { BiP }\end{array}$ & $\begin{array}{l}\text { DDIT3/ } \\
\text { CHOP }\end{array}$ & $\begin{array}{l}\text { Active } \\
\text { Caspase 3 }\end{array}$ \\
\hline $\mathrm{T}$ & $2.226 \pm$ & $9.481 \pm$ & $233.858 \pm$ & $8.600 \pm$ & $1.094 \pm$ \\
\hline II & $\begin{array}{l}0.283 \\
2.751 \pm\end{array}$ & $\begin{array}{l}0.062 \\
9.660 \pm\end{array}$ & $\begin{array}{l}2.573 \\
218.123 \pm\end{array}$ & $\begin{array}{l}0.000 \\
25.122\end{array}$ & $\begin{array}{l}0.068 \\
1.279 \pm\end{array}$ \\
\hline III & $\begin{array}{l}0.278 \\
2.531 \pm\end{array}$ & $\begin{array}{l}1.015 \\
15.210 \pm\end{array}$ & $\begin{array}{l}12.443 \\
232.685 \pm\end{array}$ & $\begin{array}{l} \pm 6.463 \\
5.234 \pm\end{array}$ & $\begin{array}{l}0.049 \\
0.826 \pm\end{array}$ \\
\hline & 0.341 & 0.000 & 5.629 & 0.890 & 0.022 \\
\hline IV & $\begin{array}{l}2.347 \pm \\
0.467\end{array}$ & $\begin{array}{l}25.900 \pm \\
0.000\end{array}$ & $\begin{array}{l}223.585 \pm \\
7.610\end{array}$ & $\begin{array}{l}2.498 \pm \\
0.330\end{array}$ & $\begin{array}{l}0.892 \pm \\
0.022\end{array}$ \\
\hline V & $\begin{array}{l}2.389 \pm \\
0.394\end{array}$ & $\begin{array}{l}36.099 \pm \\
0.152\end{array}$ & $\begin{array}{l}301.351 \pm \\
36.576\end{array}$ & $\begin{array}{l}0.720 \pm \\
0.066\end{array}$ & $\begin{array}{l}0.801 \pm \\
0.065\end{array}$ \\
\hline
\end{tabular}


pericarp extract and was still high. In this study, the administration of GML extracts reduced the oxidative stress as shown by MDA reduction, reduced the DDIT3/ CHOP level and reduced the apoptosis as shown by active caspase 3 reduction.

Table 2: MDA, AGE-CML, GRP78/Bip, DDIT3/CHOP, and active caspase 3 level in lens cortex and nucleus

\begin{tabular}{llllll}
\hline Groups & MDA & AGE-CML & GRP78/BiP & $\begin{array}{l}\text { DDIT3/ } \\
\text { CHOP }\end{array}$ & $\begin{array}{l}\text { Active } \\
\text { caspase 3 }\end{array}$ \\
\hline I & $3.340 \pm$ & $1.854 \pm$ & $138.667 \pm$ & $10.535 \pm$ & $1.857 \pm$ \\
& 0.364 & 0.316 & 0.847 & 1.676 & 0.002 \\
II & $4.709 \pm$ & $3.417 \pm$ & $228.336 \pm$ & $16.096 \pm$ & $1.710 \pm$ \\
& 0.475 & 0.170 & 13.161 & 5.51 & 0.319 \\
III & $3.687 \pm$ & $2.011 \pm$ & $201.177 \pm$ & $1.713 \pm$ & $1.324 \pm$ \\
& 0.378 & 0.628 & 19.231 & 1.179 & 0.090 \\
IV & $3.155 \pm$ & $2.301 \pm$ & $210,280 \pm$ & $6.531 \pm$ & $1.082 \pm$ \\
& 0.545 & 0.133 & 0.989 & 3.130 & 0.025 \\
V & $2.865 \pm$ & $2.628 \pm$ & $169.481 \pm$ & $4.789 \pm$ & $1.393 \pm$ \\
& 0.426 & 0.043 & 11.020 & 0.212 & 0.052 \\
\hline
\end{tabular}

Value represents as mean \pm standard deviation; Group I. Glucose $5.5 \mathrm{mM}$ (control); Group II. Glucose $30 \mathrm{mM}$ (induced); Group III: Glucose $30 \mathrm{mM}+\mathrm{GML}$ extract (100 $\mathrm{gg} / \mathrm{ml})$; Group IV: Glucose $30 \mathrm{mM}+\mathrm{GM}$ extract $(500 \mu \mathrm{g} / \mathrm{ml})$; Group V: Glucose $30 \mathrm{mM}+\mathrm{GML}$ extract $(1000 \mu \mathrm{g} / \mathrm{ml})$.

Inthelens cortexand nucleus, theadministration of high glucose concentration increased MDA, AGECML, GRP78, DDIT3/CHOP, and active caspase 3 levels. Induction with high glucose concentrations increased oxidative stress, non-enzymatic glycation, unfolded protein response (UPR), and apoptosis can be seen in Figure 2 and Table 2.

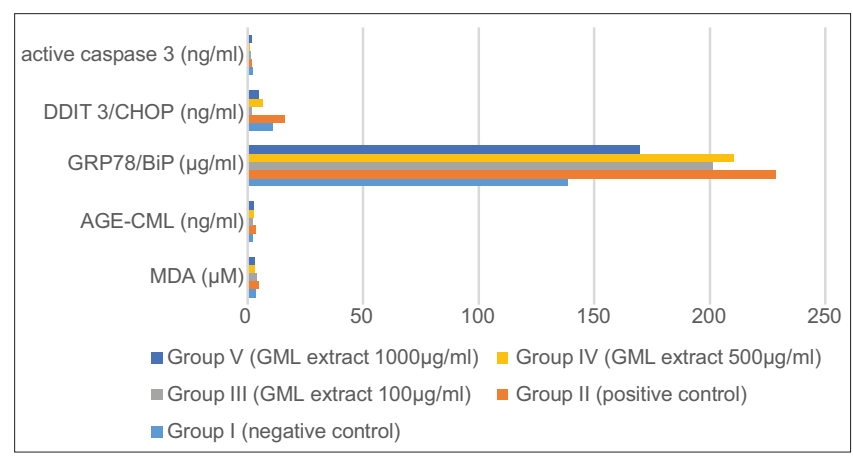

Figure 2: MDA, AGE-CML, GRP78/Bip, DDIT3/CHOP, and active caspase 3 level in lens cortex and nucleus

The administration of GML pericarp extract in Groups III, IV, and V decreased the MDA, GRP78, AGE-CML, DDIT3/CHOP, and active caspase 3 levels in the lens cortex and nucleus. GML extracts reduced the oxidative stress, non-enzymatic glycation, UPR, and apoptosis.

\section{The effect of the ethanol extract of GML}

\section{pericarp on the clarity of the lenses after $120 \mathrm{~h}$ incubation}

In Figure 3, it appears that all of the lenses in the negative control (3.A) at a Grade 1 cataract. Giving high concentrations of glucose $(30 \mathrm{mM})$ to the positive control group (3.B) causes opacity Grade 3 to goat lenses. No opacity found (Grade 0 ) in the lenses of the treated group with $30 \mathrm{mM}$ of glucose and GML pericarp ethanol extract $100 \mu \mathrm{g} / \mathrm{ml}$ (3.C) and $500 \mu \mathrm{g} / \mathrm{ml}$ (3.D). The lenses treated with $30 \mathrm{mM}$ of glucose and $1000 \mu \mathrm{g} / \mathrm{ml} \mathrm{GML}$ pericarp ethanol extract (3.E) had Grade 1 cataract.

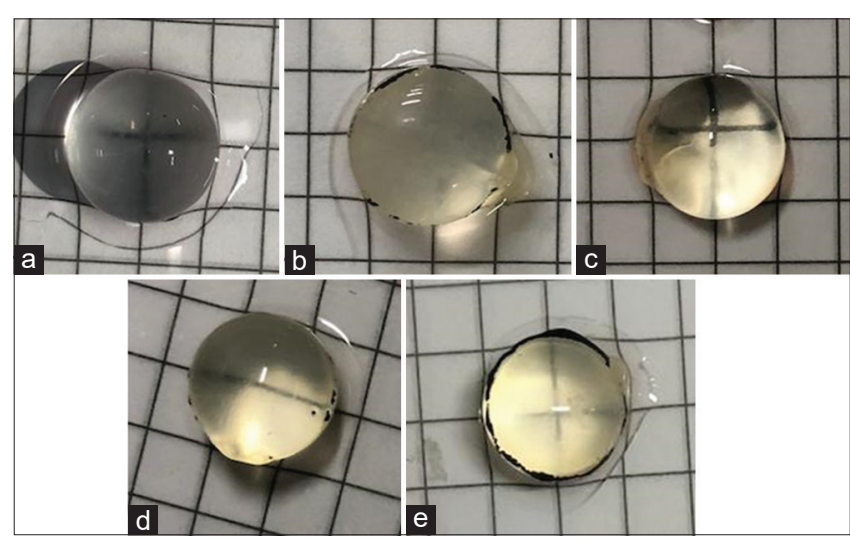

Figure 3: (a) Group I: The lenses in the negative control, (b) Group II: The lenses in the positive control, (c) Group III: The lenses with $100 \mu \mathrm{g} / \mathrm{ml}$ GML pericarp extract (d) Group IV: The lenses with $500 \mu \mathrm{g} / \mathrm{ml}$ GML pericarp extract (e) Group V: The lenses with $1000 \mu \mathrm{g} / \mathrm{ml} \mathrm{GML}$ pericarp extract

\section{Discussion}

This study aimed to prove whether the extract of GML pericarp was able to prevent oxidative stress, the formation of AGE, prevents UPR, and prevents apoptosis in high-glucose induced lens cataractogenesis.

The results of GML pericarp extraction using the reflux method using ethanol 95\% produced phytochemical content in the form of flavonoids, namely, $34.11 \pm 0.070 \mathrm{mgEQ} / \mathrm{gram}$, alkaloids $1.476 \pm$ $0.236 \%$, steroids $1.322 \pm 0.016 \mathrm{mg} / \mathrm{mL}$, saponins $1.154 \pm 0.075 \%$, and tannins $0.854 \pm 0.022 \mu \mathrm{M}$. Flavonoids and tannins are part of a group of phenolic compounds while saponins are part of a group of terpenoid compounds. The antioxidant activity of GML pericarp extract is probably a part of the phenolic element. Many phenolic compounds exhibit biological activities including antioxidant activity. Epicatechin and tannin exhibit antioxidant activity, free-radical scavenging, and protection of the skin [15].

In this study, the measurement of parameters of MDA, AGE-CML, GRP78/Bip, CHOP/DDIT3, and caspase 3 active between the lens capsule section and other parts of the eye lens (cortex and nucleus) was measured separately. The aim was to assess the changes that occur in the lens capsule and in the cortex-nucleus of the eye lens. The lens capsule, when released with the cortex-nucleus, will also carry a layer of lens epithelial cells (LECs) which are firmly attached under the capsule. These LECs are highly metabolized cells and their cleavage is very active. The cortexnucleus is composed of lens cell fibers that originate from differentiated LECs.

The human lens capsule is a basement membrane secreted by the LECs underneath and consists of a network interaction of laminin and 
type IV collagen, in addition to some heparin sulfate proteoglycans. Proteins in the basement membrane and lens capsule are types of long-lived proteins; these proteins will accumulate post-synthetic modifications of enzymatic cross-linking of amino acids, lipid peroxidation, and glycation. Glycation is the reaction of carbonyl compounds, including glucose, ascorbate oxidation products, and methylglyoxal, which form various additional structures that are stable in protein. This additional structure is collectively known as the glycation end product or AGE [16].

\section{Oxidative stress}

In the administration of high concentrations of glucose, the lens capsules have shown an increase of oxidative stress with the increased MDA levels in Group II lenses; although not statistically significant $(p=0.48)$. In the cortex and lens nucleus, oxidative stress improvement was statistically significant $(p=0.01)$. Administration of mangosteen pericarp ethanol extract at $500 \mu \mathrm{g} / \mathrm{ml}$ and $1000 \mu \mathrm{g} /$ $\mathrm{ml}$ has been shown to significantly reduce oxidative stress in the cortex and lens nucleus. In the lens capsules, the oxidative stress reduction was not statistically significant. This data are in accordance with Tjahjani's et al. (2014) study that in vitro the dose of GML pericarp extract of $500 \mu \mathrm{g} / \mathrm{ml}$ from all fractions had high DPPH trapping activity on DPPH scavenging testing compared with $\alpha$ mangosteen [17], [18].

The cells of the entire existing aerobic organisms generate the mass of chemical energy by consuming oxygen in their mitochondria. Mitochondria are the main source of ROS formation. Non mitochondrial causes of ROS comprise radiation, pollutants in food, environmental pollutants, or they are the byproducts of other metabolic processes in organisms. The majority of free radicals are generated inside the cell rather than coming from the environment [19].

Lens protein oxidation encourages the formation of covalent crosslinking and accumulation of mixed disulfide species [20]. Highly oxidized proteins are usually a large part of the protein fraction that is insoluble and soluble in cataract lens urea [21]. Oxidation of methionine residues shows that up to $50 \%$ occurs in cataract lenses and even non-cataracts can have oxidized methionine up to $37 \%$. Oxidation of cysteine residues is very usual and is a change that is first seen in the initial phases of cataract formation and increases when cataracts develop to $>90 \%$ residue in advanced cases. Tryptophan residues also showed significant oxidation in cataract affected lenses compared with healthy lenses. Certain sides of oxidation of tryptophan such as $\beta \mathrm{B} 1$-crystallin Trp192 were identified and were highly correlated with cataracts [22].
The lens is equipped with a physiological defense system to reduce ROS and maintain it at low levels. The defense system is in the form of enzymatic antioxidants, namely, glutathione peroxidase, superoxide dismutase, catalase, and chemical antioxidants, for instance, GSH, ascorbate, alphatocopherol, and beta-carotene. Structural antioxidants, namely, membrane proteins, cholesterol, and transition metal transition proteins including ceruloplasmin in the plasma and aqueous humor [23].

\section{Glycation}

AGEs are non-enzymatic protein and amino acid adducts which from dicarbonyls and glucose. AGE formation is higher in diabetes and is related to the growth of diabetic complications [12]. The accumulation of AGEs within the cataractous lens and increasing lens opacity has been documented in human lenses [7]. It is reported that level of CEL, Pentosidine, CML, and imidazole was found to be greater in diabetic lens samples than in non-diabetic samples [5].

Lens crystallins consist of $\alpha$ and $\beta$-crystallins found in lens cortex and both crystallins being abundant in lysine are more possible to experience the process of glycation. $\gamma$-crystallins is another exceptionally susceptible object for glycation and localized in nucleus [5]. In this study, non-enzymatic glycation increased significantly ( $p$ $=0.039$ ) in the administration of glucose concentration of $30 \mathrm{mM}$ in the aye lens cortex and nucleus. The lens capsules showed an increase of non-enzymatic glycation but was not statistically significant $(p=0.50)$.

The administration of GML pericarp ethanol extract was proven to reduce non-enzymatic glycation in the cortex and nucleus of the eye lens $(p=0.046)$. In the lens capsule, there was no decrease in nonenzymatic glycation, but instead a significant increase of non-enzymatic glycation $(p=0.03)$. This data show that protein glycation is more common in the lens capsule. The inhibiting activity of AGE-CML formation from mangosteen pericarp ethanol extract was only proven in the cortex and nucleus of the eye lens, not in the lens capsule.

The results of research on this lens capsule are not in accordance with Ohno's et al. study (2015) which proved the mangosteen pericarp water extract contained strong compounds that could suppress the in vitro formation of pentosidine [14], [24]. It is possible that GML does not influence the formation of CML-type AGE, may be it does affect the other types of AGE such as pentosidine and imidazole.

\section{UPR}

UPR may play an important role in diabetic cataracts. The UPR may be activated by the accumulation of unfolded proteins in the endoplasmic 
reticulum (ER) of lens fibers cells that are caused by sorbitol related stress, oxidative damage, or both [25].

In the negative control of Group (I), GRP78/ $\mathrm{BiP}$ was found at higher levels in the lens capsule compared to the cortex and nucleus of the eye lens, while DDIT3/CHOP was higher in the cortex and nucleus compared to the lens capsule. These data indicate that in physiological conditions, it is likely that more unfolded proteins in the ER of the LECs cause high GRP78/BiP protein expression in the lens capsule section. The results of our research on this goat lenses are not accordance with Torres-Berna (2014) study which found the absence of GRP78 and ATF6 in normal human lenses [25].

Induction of high concentrations of glucose caused a significant increase in GRP78/BiP and an increase in DDIT3/CHOP in the cortex and nucleus of the lens $(p=0.014)$. It may indicate that the UPR is activated as a result of ER stress within lens fiber cells under pathologic conditions. In the lens capsule, high concentration of glucose induction did not increase GRP78/BiP, but DDIT3/CHOP increased significantly $(p=0.08)$.

The administration of GML pericarp ethanol extract has been proven to reduce GRP78/BiP and DDIT3/CHOP in the cortex and nucleus of the eye lens. In the lens capsule, there was a significant decrease in DDIT3/CHOP $(p=0.04)$ without a decrease in GRP78/BiP. These data indicate that the administration of GML pericarp ethanol extract can reduce the UPR in the cortex and nucleus of the eye, although GRP78/ $\mathrm{BiP}$ in the lens capsule remained high but DDIT3/ CHOP decreased significantly. It is possible that the GML pericarp ethanol extract had another pathway in DDIT3/CHOP inhibition besides UPR pathway. The decrease in DDIT3/CHOP was significant with GML pericarp ethanol extract doses of $100 \mu \mathrm{g} / \mathrm{ml}, 500 \mu \mathrm{g} / \mathrm{ml}$, and $1000 \mu \mathrm{g} / \mathrm{ml}$. The decrease in active caspase 3 was significant with the administration GML pericarp ethanol extract doses of $100 \mu \mathrm{g} / \mathrm{ml}, 500 \mu \mathrm{g} / \mathrm{ml}$, and $1000 \mu \mathrm{g} / \mathrm{ml}$.

\section{Apoptosis}

The lens epithelium is considered to shield underlying fibers from injury and maintain the transparency of the lens. Damage to LECs is considered to be a key factor in diabetic cataractogenesis. Kim et al. discovered that the death of LECs caused by apoptosis and that the blockade of apoptosis reduced the formation of cataract [26].

Based on the active caspase 3 data in this research, it appears that in the negative control group apoptosis was more common in the cortex and nucleus of the eye lens than in the lens capsule. The apoptosis is more common in lens fiber cells. Induction with the high concentrations of glucose caused a significant increase ( $p=0.011$ ) of apoptosis of epithelial cells in the lens capsule. The administration of GML pericarp ethanol extract caused a significant decrease in apoptosis both in the lens capsule and in the cortex and nucleus of the eye lens. The data show the anti-apoptotic activity of the GML pericarp ethanol extract.

Wang et al. also found that apoptosis of LECs is a core link of diabetic cataract, high blood glucose can increase the apoptosis of LECs. The expression of p53 protein and $\mathrm{Bcl}-2 / \mathrm{Bax}$ pathway was implicated in the regulation of apoptosis process of LEC [27].

\section{Conclusion}

On the lens capsule, ethanol extract of GML pericarp potentially showed antioxidant, DDIT3/CHOP inhibitor, and anti-apoptotic activity. On the cortex and nucleus of the lens, ethanol extract of GML pericarp potentially showed antioxidant, antiglycation, DDIT3/ CHOP inhibitor, and anti-apoptotic activity in cultured lenses. More studies are required to investigate details of increase mechanism of AGE-CML and GRP78 on the lens capsule.

\section{References}

1. International Diabetes Federation. IDF Diabetes Atlas. $9^{\text {th }}$ ed Brussels, Belgium: International Diabetes Federation; 2019. Available from: https://diabetesatlas.org/en/sections/worldwidetoll-of-diabetes.html

2. Boyle JP, Thompson TJ, Gregg EW, Barker LE, Williamson DF. Projection of the year 2050 burden of diabetes in the US adult population: Dynamic modeling of incidence, mortality, and prediabetes prevalence. Popul Health Metr. 2010;8:29. https:// doi.org/10.1186/1478-7954-8-29

PMid:20969750

3. Grzybowski A, Kanclerz P, Huerva V, Ascaso FJ, Tuuminen R. Diabetes and phacoemulsification cataract surgery: Di-culties, risks and potential complications. J Clin Med. 2019;8(5):716. https://doi.org/10.3390/jcm8050716

PMid:31137510

4. Negre-Salvayre A, Salvayre R, Auge N, Pamplona R, PorteroOtın M. Hyperglycemia and glycation in diabetic complications. Antioxid Redox Signal. 2009;12(11):3071-109. https://doi. org/10.1089/ars.2009.2484

PMid:19489690

5. Hashim Z, Zarina S. Advanced glycation end products in diabetic and non-diabetic human subjects suffering from cataract. AGE. 2011;33(3):377-84. https://doi.org/10.1007/s11357-010-9177-1 PMid:20842534

6. Sayin N, Kara N, Pekel G. Ocular complications of diabetes mellitus. World J Diabetes. 2015;6(1):92-108.

PMid:25685281

7. Peterson SR, Silva PA, Murtha TJ, Sun JK. Cataract surgery in patients with diabetes: Management strategies. Semin Ophthalmol. 2018;33(1):75-82. https://doi.org/10.1080/088205 


\subsection{7 .1353817}

PMid:29144826

8. Peyroux J, Sternberg M. Advanced glycation endproducts (AGEs) Pharmacological inhibition in diabetes. Pathol Biol (Paris). 2006;54(7):405-19. https://doi.org/10.1016/j.patbio.2006.07.006 PMid:16978799

9. Wu CH, Huang $\mathrm{SH}$, Lin JA, Yen GC. Inhibition of advanced glycation endproduct formation by foodstuffs. Food Funct. 2011;2(5):224-34. https://doi.org/10.1039/c1fo10026b PMid:21779560

10. Kumar PA, Reddy GB. Modulation of $\alpha$-crystallin activity: A target to prevent or delay cataract? IUBMB Life. 2009;61(5):485-95. https://doi.org/10.1002/iub.176

11. Lim V, Schneider E, Wu H, Pang LH. Cataract preventive role of isolated phytoconstituents: Findings from a decade of research. Nutrients. 2018;10(11):1580. https://doi.org/10.3390/ nu10111580

PMid:30373159

12. Brings $\mathrm{S}$, Fleming $\mathrm{T}$, Freichel $\mathrm{M}$, Muckenthaler MU, Herzig $\mathrm{S}$, Nawroth PP. Dicarbonyls and advanced glycation end-products in the development of diabetic complications and targets for intervention. Int J Mol Sci. 2017;18(5):984. https://doi. org/10.3390/ijms18050984

PMid:28475116

13. Obolskiy D, Pischel I, Siriwatanametanon N, Heinrich M. Garcinia mangostana L.: A phytochemical and pharmacological review. Phytother Res. 2009;23(8):1047-65. https://doi. org/10.1002/ptr.2730

PMid:19172667

14. Ohno R, Moroishi N, Sugawa H, Maejima K, Saigusa M, Yamanaka $\mathrm{M}$, et al. Mangosteen pericarp extract inhibits the formation of pentosidine and ameliorates skin elasticity. $J$ Clin Biochem Nutr. 2015;57(1):27-32. https://doi.org/10.3164/ jcbn.15-13

\section{PMid:26236097}

15. Ngawhirunpat $T$, Opanasopi $P$, Sukma $M$, Sittisombut CC Kat A, Adachi I. Antioxidant, free radical-scavenging activity and cytotoxicity of different solvent extracts and their phenolic constituents from the fruit hull of mangosteen (Garcinia mangostana). Pharm Biol. 2010;48(1):55-62. https://doi. org/10.3109/13880200903046138

PMid:20645756

16. Danys BP, Duncan MK. The lens capsule. Exp Eye Res. 2009;88(2):151-64. PMid: 18773892

17. Sukatta U, Takenakan M, Ono H, Okadome $H$, Sotome I, Nanayama $\mathrm{K}$, et al. Distribution of major xanthones in the pericap, aril, and yellow gum of mangosteen (Garcinia Mangostana Linn.) Fruit and their contribution to antioxidative activity. Biosci Biotechnol Biochem. 2013;77(5):984-7. https:// doi.org/10.1271/bbb.120931

\section{PMid:23649258}

18. Tjahjani S, Widowati W, Khiong K, Suhendra A, Tjokropranoto R Antioxidant properties of Garcinia mangostana L (mangosteen) rind. Procedia Chim. 2014;13:198-203. https://doi.org/10.1016/j. proche.2014.12.027

19. Poljsak B. Strategies for reducing or preventing the generation of oxidative stress. Oxid Med Cell Longev. 2011;2011:15. https:// doi.org/10.1155/2011/194586

20. Moreau KL, King J. Protein misfolding and aggregation in cataract disease and prospects for prevention. Trends Mol Med. 2012;18(5):273-82. https://doi.org/10.1016/j. molmed.2012.03.005

PMid:22520268

21. Yanshole LV, Yanshole VV, Snytnikova OA, Fursova AZ, Kolosova NG, Tsentalovich YP, et al. Effect of SkQ1 eye drops on the rat lens metabolomic composition and the chaperone activity of $\alpha$-crystallin. Dokl Biochem Biophys. 2015;464:341-5. https://doi.org/10.1134/s1607672915050191 PMid:26518564

22. Hains PG, Truscott RJ. Age-dependent deamidation of lifelong proteins in the human lens. Invest Ophthalmol Vis Sci. 2010;51(6):3107-14. https://doi.org/10.1167/iovs.09-4308 PMid:20053973

23. Nita M, Grzybowski A. The role of the reactive oxygen species and oxidative stress in the pathomechanism of the agerelated ocular diseases and other pathologies of the anterior and posterior eye segments in adults. Oxid Med Cell Longev. 2016;2016:23. https://doi.org/10.1155/2016/3164734.

24. Abdallah HM, El-Bassossy H, Mohamed GA, El-Halawany AM, Alshali KZ, Banjar ZM. Phenolics from Garcinia mangostana inhibit advanced glycation endproducts formation: Effect on amadori products, cross-linked structures and protein thiols. Molecules. 2016;21(2):251. https://doi.org/10.3390/ molecules21020251

PMid:26907243

25. Torres-Berna BE, Torres-Bernal LF, Gutierrez-Campos RR, Stalnikowitz DK, Barba-Gallardo LF, Chayet AA, et al. Unfolded protein response activation in cataracts. J Cataract Refract Surg. 2014;40(10):1697-705. https://doi.org/10.1016/j. jcrs.2014.02.038

PMid:25263040

26. Kim B, Kim SY, Chung SK. Changes in apoptosis factors in lens epithelial cells of cataract patients with diabetes mellitus. J Cataract Refract Surg. 2012;38(8):1376-81. https://doi. org/10.1016/j.jcrs.2012.04.026

PMid:22727992

27. Wang HM, Li GX, Zheng HS, We XZ. Protective effect of resveratrol on lens epithelial cell apoptosis in diabetic cataract rat. Asian Pac J Trop Med 2015;8(2):153-6. https://doi. org/10.1016/s1995-7645(14)60307-2

PMid:25902031 